\title{
The Precariat, Class and Progressive Politics: A Response
}

\section{Guy Standing, School of Oriental and African Studies, England}

In a short article, it is impossible to respond to all the points made in the papers, especially as they have marked differences. I should begin by thanking the authors for engaging with the analysis, and apologising if I do not refer to every point they have made. What this note tries to do is trace the origins of the concept, and reiterate why I believe the precariat is a class-in-the-making and why it is a global, not "Eurocentric" or "Northern" phenomenon, as Ben Scully contends.

Some of the points for the defence are similar to those given in response to an article by Jan Breman; several of the commentators cite his article, but not my two ripostes (Standing, 2014a, 2014b). ${ }^{1}$ To save space for other comments, I have tried not to repeat points made in those, but just make reference to them.

\section{Origins of the Precariat}

None of the commentators mentioned the two starting points in the books, although Jenny Chun alludes to one of them. That is the distinction between labour and work. The commentators use the words synonymously; the books do not. Essentially, work has use value, labour has exchange value, and the precariat is defined in part by having to do a lot of work-for-labour and for being exploited off the workplace and outside labour time. ${ }^{2}$

A second key distinction is the Marxian one between labour and labour power. A critic may disagree with those distinctions, but he cannot criticise fairly unless he recognises what is crucial for the author. It is partly because he ignores these distinctions that Erik Wright fails to understand the precariat. But it is also misleading for Scully to say I "describe contemporary precarious work" (161). ${ }^{3}$ It is not work or labour that is precarious. One could be doing unstable labour, through a series of short-term or casual jobs, and not be in a precarious situation. In fact, if anything, I would favour jobs being casual if they were onerous, boring or limiting, which for most in the precariat today is the reality.

In the three books dedicated to analysis of the precariat, each has begun by emphasising the centrality of those distinctions. This was done most systematically in the first, which was intended to be the most "academic" and global in character (Standing, 2009), although it also figured in earlier work (Standing, 1999).

\footnotetext{
${ }^{1}$ As mentioned in Standing (2014a), the editor of the journal in which Jan's article appeared refused me a right of reply, a regrettably illiberal tendency in some "leftist" quarters.

2 Although Erik Wright says it is less important than others in the Charter, Article 1 on the need to reconceptualise work (and its derivative, Article 2) was given precedence for a reason, which is that it is crucial. It highlights a key to understanding why the precariat's "interests" differ from those of the proletariat and salariat.
}

${ }^{3}$ When page numbers are presented thus, they refer to the page within this Special Issue. 
A third conceptual tool on which the analysis rests is social income. Essentially, this refers to all possible forms of income, and one finds different structures in different types of economic and systemic changes in the structure or composition of social income. Since Scully in particular has misinterpreted this, it will figure prominently in the final section on "the South" and the spurious "Golden Age".

A fourth distinction that is important in my mind (rightly or wrongly) is between proletarianisation and precariatisation. I first analysed the former in working in the slums of Kingston, Jamaica, and Georgetown, Guyana, many years ago. The context was the historical transition from a slave-based economy to an indentured-labour economy, and then to an ongoing urban proletarianisation.

What that latter term means is the process of indoctrinating or habituating workers to supplying stable, dependable labour, disciplined by the clock. It was brilliantly analysed by a generation of Marxist historians, notably E.P. Thompson, Eric Hobsbawm and Maurice Dobb. By contrast, the concept of precariatisation is intended to mean the process by which those in the precariat are being habituated to accept a life of unstable labour and unstable living as supplicants.

\section{The Issue of Class}

What seems to bother a lot of commentators is whether or not the precariat is a class. Erik Wright has reproduced a long article on this, and accordingly much of this rejoinder should discuss it, since it is intended to be a rebuttal. Due to space constraints, I will concentrate on the key issues. Before doing so, note that Scully mixes up "detachment from labour" with "relations of production". The latter helps to define the precariat as a class, in my framework, whereas the former is, as stated in the book, a "psychological detachment" - that is, a subjective feature of being in the precariat. As I have stated often, it applies to pre-capitalist social formations as well. But it takes a particular exciting form in the case of the precariat.

The point is that being psychologically detached is good, not bad, since it makes it less likely that somebody will suffer from false consciousness, that labour is wonderful. I ended Chapter 1 of A Precariat Charter by making the political point, "But since the precariat is emotionally detached from the labour it is expected to do, it is less inclined to imagine that jobs are the road to happiness or that job creation is a sign of social progress" (Standing, 2014c: 32). That may be right or wrong, but a reader should be able to see this is making a point about consciousness, not definition.

So, to Wright's critique. He says class is defined by material interests and that my definition in terms of combinations of distinctive relations of production, relations of distribution and relations to the state is inadequate. According to him, I give none of the three dimensions "more weight than others" (125). I have done this in several articles, and will just say in passing that in terms of relations of production heavy weight should be given to lack of an occupational narrative, because this is what work is about in the realm of freedom. ${ }^{4}$ In terms of relations to the state, the most

\footnotetext{
${ }^{4}$ Class should be about alienation as well as about exploitation and control. In an important branch of Marxian thought, associated with Istvan Meszaros et al., alienation is central to class analysis. Marx in stodgy Hegelian terms referred to buman essence. In Work after Globalisation (Standing, 2009), I tried to give a modern flavour by focusing on work as occupation, which is about what we do and how we can or cannot develop our capabilities (labour power). When commentators use employment security and job security synonymously, they miss the point. They are not the same. In juxtaposition to Wright's perspective, to put the occupational point aphoristically, there is more to life than material
} 
significant aspect is that those in the precariat are supplicants. The latter is the most important aspect, and is the etymological root of precarity.

Be that as it may. The question I would pose to any reader of Wright's article is: Does the way he describes "material interests" and thus "the working class" give a clearer or more useful way into understanding the reality of the precariat and proletariat than the way described in the precariat books, even as reproduced rather unsympathetically by Wright? If it does, then use his approach. I find it too abstract and feel the lack of differentiation is a block to analysis. Others may think differently.

A puzzle when reading Wright's work is to decide whether his claim to be Marxist is justified. There is no focus on relations or forces of production, or incorporation of dialectics. ${ }^{5}$ For him the working class is an unchanging phenomenon in the game of capitalism, which has "fixed rules". At times one feels his all-embracing working class is a mirage. If it is defined as all those having the same "material interests", and if one were to show that one group (say, the precariat) had different material interests from another (say, the proletariat), he would presumably just say they have "contradictory locations". 6

The trouble is that he seems unable to define "material interests", which he admits "raises a host of tricky theoretical issues". You bet. If I were to write that about the precariat, I suspect Wright would say it proves the concept is too hazy. He then flip-flops on "objective interests", concluding that they are "propositions" and thus not proven. If one says one does not know what material interests are, it is surely dubious to define a class by them. He then asserts that material interests mean "for any given person it is possible to identify actions and social changes which would improve or harm their material conditions of life". Sometimes I wish life were so simple. ${ }^{7}$ Later he says that "objectively definable material interests are a legitimate criterion for differentiating class locations". This is either a grammatical slip (interests being plural) or implies there are other criteria as well. My reading of Wright's work is that for him material interests are the only criterion.

I confess to being almost allergic to analysis by metaphor, particularly sporting metaphor. Wright talks about "the game of capitalism" and about "the games of capitalism". He also speaks of "varieties of capitalism" in the game or games (but not varieties of working class). And he claims the game of capitalism has a "fixed set of rules". Then, making the metaphor more confusing, he admits, "Multiple 'games' are being played simultaneously with often inconsistent rules". This approach seems fundamentally non-Marxist.

In trying to "clarify this framework", he gives a long footnote on short and tall athletes and

interests.

${ }^{5}$ Contrary to Wright's snide assertion (125) that I am not interested in "a rigorous general class map of contemporary capitalism", the book to which he refers states this is done elsewhere (Standing, 2011: 91). My initial attempts to produce a broad class conceptualisation concentrated on control, or in Marxian terms, determination, which implies contestation. The idea was that one should identify modes of exploitation, modes of control and modes of alienation. The perspective drew inspiration from the late C.D. Cohen and Barrington Moore, inter alia.

${ }^{6}$ To complicate matters further, Wright allows for people to be in a primary class and a secondary class (134, f.12). Or is it two primary classes?

7 As Wright uses sports metaphors in his paper, let me give a sporting example. He may say that going for a run in the morning would improve my "material conditions of life". Without realising it, I may have a weak heart. All of us take actions that may or may not improve our conditions of life and we rarely know which is which. Life is full of probabilities and risks. 
the game of basketball. Later, when wriggling to escape the reality that some in his all-embracing notion of a working class do not have the same "material interests", he resorts to his well-known tool of saying they have "contradictory locations".

As if it is a clincher, Wright also uses an old sentimental poster of a woman standing by a fence, saying, "Class consciousness is knowing which side of the fence you're on." I suppose if somebody has simultaneously (his word) contradictory class locations, the woman in the poster would be sitting on the fence, which could be painful. Given his choice to use sports metaphors, one might say that Lionel Messi would be in a contradictory location if he were playing for Barcelona and Real Madrid simultaneously. That just does not make sense.

The second of the poster's aphorisms seems more fertile: "Class analysis is figuring out who is there with you." It is a punchy line, but when one gets over the emotional tug it should prompt a Marxist to be dialectically critical. To put it bluntly, many in the precariat do not believe many in the proletariat or salariat are "there with them". But I suspect Wright would deny that making such a point is class analysis because, according to him, they all have the same material interests, and - as we shall see - the same location. If I were to use the term material interests, or understand it clearly, my claim would be that they do not have the same interests or location. For instance, one reason for treating the modern salariat as a separate class rather than as part of one big working class is that its modal members receive a large and growing part of their social income from capital, and gain from cuts in wages and state benefit contributions from income. They do not share a common economic interest with the proletariat or precariat.

Wright follows his citing of the sentimental poster by concluding (128), "So, to claim that the working class and the precariat are distinct classes is to claim that they have distinct material interests." But I do not use his term "material interests", and so do not make the claim he implies. What I do claim, for better or worse, is that the groups have distinctive combinations of relations of production, relations of distribution and relations to the state. I refuse to have words put into my mouth.

On reading Wright's piece it became clear he had used a device designed to discredit my analysis. Bear in mind that my claim is that there has been class fragmentation, so that the old nomenclature is no longer fit for understanding the dynamics of class struggle. Another way of putting this is that differences within bloc concepts, such as the bourgeoisie/capitalist class and working class, have grown to the point of splitting them. This may be correct or incorrect. But if you are making a critique, you should do the author the courtesy of describing his framework correctly. I do not do what Wright claims, which is compare the precariat with "the working class". The distinction is between the precariat and proletariat, which he acknowledges in one place (125). The latter makes sense, the former does not.

This may be partly my fault, in that for a while I could not find a comfortable terminology to describe those who were not moving into the salariat or precariat. In some places, the term proletariat is used for core workers, as in the first book (Standing, 2009). ${ }^{8}$ However, it should be clear that, while capitalists have split into a plutocracy and an elite (the one receiving income mainly from rent, the other from corporate profits and rent), the working class has fragmented into four salariat, proficians, proletariat and precariat. That is the claim. They are defined by unique

\footnotetext{
${ }^{8}$ A reason for the discomfort was that I was trying to avoid old terms that block progressive thinking. This also applied to time-honoured notions of bourgeoisie and "middle class", in either the American or European sense.
}

Global Labour Journal, 2016, 7(2), Page 192 
combinations of relations of production, relations of distribution and relations to the state, all Marxian concepts. Whether right or wrong, it is unfair to say I compare the precariat with "the working class". The comparisons are between the precariat and the salariat, proletariat (core) and proficians. Surely they have different "interests" as defined by the three dimensions.

Wright misrepresents the definition of the precariat's relations of production. He says (125) that the absence of the first five forms of labour security defines the precariat's relations of production. I did not say that; it does not make sense. ${ }^{9}$ On the page where the seven forms of labour security are listed, I said merely that the precariat lacks all of them, not that the lack of them defines the relations of production. Where I do define them I do so to compare them with the norms of the proletariat (Standing, 2014c: 16-18). Again, one might disagree with the distinctions but surely they are clear. What I have done in papers and talks since writing the book is include three other aspects - that the precariat has no occupational or corporate narrative, that this is the first "working" class in which the modal level of education is greater than the labour they are expected to perform, and that the precariat has to do a high ratio of work-for-labour to labour.

Incidentally, while on relations of production, Ruy Braga claims I believe "precariousness is a condition located outside the wage relationship" (151; his emphasis) and that I define the precariat "as the antipode of wage labour, as a repressed "bastard". I do not see how one can read that into the definition. The precariat is defined in part as being forced to accept unstable wage labour. By contrast, Braga thinks the "wage relation" results in "the institutionalisation of citizenship rights". That is the labourist fallacy. He adds, "Standing identifies the particularity of Fordist citizenship with the totality of the wage relation" (151). I do not understand what that means, but have definitely never made any such identification. Fordism is a way of organising mass labour, which has nothing to do with proper citizenship.

Anyhow, Wright's summary of the precariat's distinctive relations of distribution is roughly correct, although he omits aspects that I regard as critical. These are that the precariat is systematically exploited off the workplace and outside labour time through unpaid work-for-labour, is systematically exploited through debt, and is subject to systemic poverty traps and precarity traps.

In discussing relations to the state, Wright notes the contrast between "citizens" and "denizens". But what I tried to do was sketch a process, stating "today it would be better to think of citizenship as a continuum, with many people having a more limited range of rights than others, without any simple dichotomy of citizen and non-citizen" (Standing, 2014c: 8). In a box, I proposed modal differences in the strength of the five types of rights in the class groups, presented as a hypothesis, since I am unaware of anybody having presented them in terms of class (Standing, 2014c: 20). I and others have been doing more on this, and several conferences are under preparation. It is the process of loss of acquired rights that is so distinctive and interesting for research and political action.

Later, Wright (127) refers to my statement on existing divisions within the precariat (as if there are none in other classes, his preferred umbrella working class included). He adds, presumably sarcastically, “And yet, in spite of this, he believes it has the potential to become a 'dangerous class' much more capable than the working class of challenging 'the mainstream political agendas of the twentieth century, the neo-liberalism of the mainstream "right" and the labourism of social democracy' (Standing, 2014: 31)".

This splices something said on page 29 of the book with something on page 31 (Standing,

${ }_{9}$ Thus the first, labour market security, refers to the level of job opportunities; the fifth to health and safety. 
2014c). The point about internal divisions was that the precariat needs to become enough of a classfor-itself to become politically powerful for its own agendas. The sentence on divisions that Wright quotes was followed by, "This may change sooner than some observers imagine." It was a bit mean to omit that.

He then misinterprets the concept of a dangerous class. In the nineteenth century, the term was used in several ways, the most fruitful being to refer to craftsmen and street-traders who were not part of the bourgeoisie or growing proletariat. ${ }^{10}$ In London and other British cities, they were regarded as dangerous because they defended the values of work over the dictates of labour and because they challenged the bourgeois morality, the proletarian morality and the pretences of finance. ${ }^{11}$

There is also another tradition, which is that a class that has not established a class consciousness is liable to be led by populist sirens, as I warned in The Precariat and reiterated on page 32 of A Precariat Charter. Wright's misinterpretation of a dangerous class is further shown by the second bit of splicing. I did not say the precariat was "'more capable than the working class of challenging the mainstream, etc." Nor was the opposite stated. The passage merely stated that "its class interests are opposed to the mainstream...." This is not a semantic point. The contention is that the precariat has class interests that differ from those of the proletariat and salariat. The proletariat is unlikely to challenge mainstream labourism at all. As is argued in the final chapter of the book, on some issues there will have to be class coalitions if the policy or institutional change is to have a high chance of success.

In the end, Wright wants to defend a nineteenth-century dualistic class model, even though Marx left his analysis tantalisingly incomplete. Wright's all-embracing working class means that, for him, everybody in it has the same material interests and common views on the game or games of capitalism, and the rules of the game. This is either confusing or tautological. It may be the latter, because in introducing the notion of contradictory locations, any instance of groups not having the same interests can be attributed to their being in a contradictory location.

Wright asserts that "people within a given class should share broadly similar optimal strategies". But he does not apply that to his own framework, since he admits that some people have "contradictory locations". If so, how could they have the same strategies, or even the same shortterm or long-term goals? It might make more sense to say they should want similar outcomes. But that would also be too restrictive. There is no reason for thinking that the proletariat would have the same "optimal strategy" as the precariat.

Wright does not define the working class. But he goes from talking at length about games, fixed rules of games and undefined material interests to posing a rhetorical question about the precariat's attitudes to "the game itself, rules of the game and moves within the existing game". He then talks about a socialist alternative to capitalism being "possible" but "not achievable in current circumstances". It is all very abstract and esoteric. Surely, progressive thinking should be about what is desirable and achievable - real utopias, perhaps.

\footnotetext{
10 Sadly, as stated in all three books, their voices in favour of the values of work over labour lost out as the "material interests" of the proletariat and bourgeoisie triumphed in twentieth-century labourism. In particular, the theme was central to the longer earlier book, Work after Globalisation (Standing, 2009).

${ }^{11}$ I have discussed this elsewhere. For an excellent discussion of how the term was used in newspapers and among radical thinkers at the time, see Jankiewicz (2012).
}

Global Labour Journal, 2016, 7(2), Page 194 
He then asserts, "the precariat and the working class clearly occupy the same location within the class structure" (132). ${ }^{12}$ If he means the proletariat or salariat, I disagree. The groups do not have the same relations of production, relations of distribution and relations to the state. Therefore, logically, they cannot have the same "location".

He then says that "the material conditions of life for people in both locations within capitalism would be enhanced in an alternative economy built around various forms of social ownership..." (132). If they are in the same location, how they can be in two locations? The slip just shows the muddle involved in going down this route.

One could say that if one takes an evolutionary socialist perspective (as Wright protests he does), then one would have no difficulty in envisioning a course of evolution towards his abstractly defined "democratic socialism" (132) that would benefit the proletariat but disadvantage the precariat. The journey matters. The interests are not the same, the locations are not the same, and the optimal strategies (whatever they are) to reach somewhere are not the same. End of game.

Finally, he returns to his fence image, asking rhetorically, "Are they on the same side of the fence or opposite sides when 'the fence' is defined by struggles over the rules of capitalism?" My reaction to reading that was, "It depends on what rules we are talking about". Suppose it was rules on employment security or non-wage benefits, then strengthening them for long-term, full-time employees would be welcomed by the proletariat but opposed by the precariat. One could give numerous other examples. But perhaps they are not "rules".

Article 1 of $A$ Precariat Charter is a touchstone issue showing that representatives of the proletariat - socialists, trade union leaders and academic fellow-travellers - have been consistently on one side, whereas the precariat, feminists and ecologists have been on the other. The rules have been that only labour has "rights", not other forms of work. This leads to consideration of the roles of trades unions.

\section{Unions, Occupy Movements and Recognition}

All the commentators are defensive of labour unions. Marcel Paret is also defensive about Occupy. On the latter, he misquotes and makes a false claim. Nowhere have I written or thought that "the most downtrodden should be expelled from the movement" (183). This is preposterous and contrary to everything I believe. My point about the Occupy movements - and I spoke at several, and participated in others - was that they helped advance a sense of class recognition, and were not, as some on the left have contended, a failure. It is also unfair to say the camps were only about recognition. Of course they were not. My point is that advancing the sense of recognition was a major step forward.

On labour unions, there are contradictory claims. Some of the commentators say I am hostile to them and predict and want them to die. By contrast, Chun claims I suffer from "historical amnesia" in "celebrating historical patterns of industrial labour organising" that were exclusionary of women and other groups (137-138). In fact, I have been consistently critical of unions for being exclusionary and labourist, and for not recognising work that is not labour.

Ray Braga's critique is twofold. First, he claims I see a fundamental cleavage between trade unions and the precariat, whereas he believes unions, at least in Brazil and Portugal, are

${ }^{12}$ Underlining in this and the following paragraphs are added. 
"compatible" with and collaborating with the precariat (155). Second, he believes the precariat should mobilise around a fight for social rights rather than a basic income. He concludes (157), "it is clear that there is no truly credible reason for the precariat to defend the Universal Basic Income as a priority flag of mobilisation". Why not do both?

He also attributes to me a view that is a strange reading of $A$ Precariat Charter by saying "Standing has decided to confine the political praxis of the precariat to the field of reform of public policies." He claims I ignore collective action. Yet Articles 5 to 10 of the Charter are devoted to options for strengthening collective action and representation, and not public policies as conventionally defined. The precariat must develop independent bargaining strength within occupations and also against the state. The thrust of the Charter is to revive the Great Trinity, and to strengthen individual and collective Voice as well as basic economic security, and thus the capacity to abolish the conditions that define the precariat and thus abolish itself. It is this dialectic that defines it as today's potentially transformative class.

With perhaps commendable loyalty, Braga protests too much on behalf of unions in Brazil and Portugal. If they were responding so well to the precariat's needs and aspirations, the organisations set up to represent it would not have been needed. All I can say is that my contacts with some of the precariat bodies he mentions have revealed a strong sense of grievance against unions and a difference of ideology and orientation.

An acid test for Braga is simple: How many of the young precariat have been joining mainstream unions in Brazil or Portugal? In both countries, the established unions have been representing, primarily, older proletarian employees and have been trying to defend labour-based entitlements built up over the years. I see nothing illegitimate in that. Indeed, it is an honourable function. Yet, we should be realistic and admit that this is not an agenda that strengthens the economic security of the precariat, and does not correspond to the priorities or ideology of the progressive part of the precariat.

Now consider the recent mass protests in both Portugal and Brazil. What have they been about? They have been mainly collective protests against cuts, against austerity, against erosion of social rights, against political corruption, and so on. They are in terms used in the books, the protests of "primitive rebels", united actions of convenience. They are not collective action in favour of a particular vision of a Good Society in the future. Let there be no misinterpretation. Society needs collective bodies representing vulnerable classes. We need unions. Without collective bodies we all remain vulnerable before capital and the neo-liberal state. But labour unions, while needed to protect the interests of the proletariat, cannot structurally represent the primary interests of the precariat.

Once again, let me reassure critics such as Eric Wright and Ruy Braga who leap to the defence of trades unions. I have been a unionist all my life, and have written and spoken in defence of them, even losing jobs over my opinions. Braga claims I "underestimate" trade unionists. But labour unions are indicators of why Wright's position is wrong.

Since early in the twentieth century, they have defended labourism. They have never allowed the same "rights" to those doing work that is not labour. They have advanced the "rights of labour" (sic). A symbolic example is ILO's Convention 102 of 1952, known as the Social Security Convention. It has been defended vigorously by the world's unions, which managed to have it declared in 2001 one of the "up-to-date" international conventions. In reality, it is a parody of the male breadwinner model of labourism geared to the stable proletarian seen as the zenith of socialism 
and social democracy of the 1950s. Anybody in the precariat should want it discarded without a moment's delay. One should be more impressed by positions taken by unions with respect to such conventions than by an act of ensuring one person can use a toilet of her choice (154).

The key questions we should pose with respect to unions (of course there are others) are: Do they support the decommodification of labour power or the decommodification of labour? Would they support job creation or retention over ecological damage? I have over the years interacted with hundreds of union leaders and officials, and can say honestly that I have too rarely had satisfactory answers to those questions. ${ }^{13}$ Essentially, labour unions have opted for labour decommodification and defended it for their members, and have consistently opted for jobs over environmental decay, as outlined in the preface to the Spanish edition of The Precariat, given the Spanish unions' atrocious record in that respect.

Let there be no misrepresentation. Collective bodies are needed. But today it is the unions that must be transformed if they are to represent the needs, insecurities and aspirations of the precariat.

\section{The Global South and North}

Social concepts in general are not so much right or wrong, but useful or not for the person using them. Thus, I have never understood what "the Global South" means, or "the Third World", terms that Ben Scully uses. They imply there is an adequate homogeneity covering over 150 countries.

I also cannot understand why scholars still use the term "the informal sector" when it has defied definition and measurement for over forty years. What is extraordinary is that critics who claim the precariat is a vague concept use these other terms remarkably loosely. When Jan Breman, for instance, says that 93 per cent of the Indian labour force is in the informal sector, he is cramming far too much into an undefined notion. Scully adds to my confusion when he talks of "the Southern working class". Does this include both the Masai rural dwellers and the urban proletariat of Lagos or Johannesburg, Indian peasants and call centre labourers in Bangalore?

That is not the problem here. I want to address the themes that shape Scully's critique. He says repeatedly that I trace the growth of the precariat to "a decline from a golden age" (163), but the books explicitly reject the notion of any golden age. Some years ago I was invited by New Left Review to review Richard Sennett's book The Corrosion of Character, which was a lament for what he saw as a decline from the golden age of US capitalism. My view was that it had been a drab period of labourism.

In Work after Globalisation, I condemned it as one that gave a privileged group of men employment security, entrenching gender and other forms of insecurity and inequality, and concluded, "Elderly male commentators who refer to the period with misty eyes as a 'Golden Age'

\footnotetext{
13 I recalled in the book how I once asked a group of senior trade unionists why unions had been the most vehemently opposed to a basic income, given that it was designed to give everybody basic security. Although the chair tried to close off the discussion at that point, one leader stood up and said that he thought it was because if people had basic security they would not join unions. So much for having the same material interests. I believe people with basic security are actually more likely to join collective bodies and in any case, unions should be about wider issues. As it happens, this rejoinder was written mainly while I was in Finland advising on the government's planned basic income pilot, by which everybody in one or several communities would receive a basic income paid unconditionally, without any other change in policy. Guess which two were the only groups to oppose the idea, even that there should be a pilot? Yes, the Social Democrats and the trades unions. How anybody can think there are common material interests and common strategies in the light of such realities defies reason.
}

Global Labour Journal, 2016, 7(2), Page 197 
should be reminded of that" (Standing, 2009: 38). So to base a critique on the opposite of what I believe is hardly a good start. There was no golden age. I am mildly optimistic that we are finally seeing a break from the drabness of labourism, which befuddled socialists and social democrats for far too long.

Scully's misreading on the golden age goes with his misreading of detachment from labour. This is positive, avoiding false consciousness. That is why I gave prominence to the subversive piece of graffiti, "The worst thing would be to go back to the old normal". That I used it at the beginning and end of the book should have alerted a reader to the fact that I did not regard the past as some golden age.

Now to the claim that I ignore the "Global South", am Eurocentric, use "simplistic assumptions" and look through the "political lenses derived from the Northern experience". ${ }^{14}$ Some of Scully's misconceptions are similar to those of Munck and Breman and are answered elsewhere (Standing, 2014a, 2014b). But I think his particular problem stems from a failure to understand the concept of social income, typified by his statement, "So the picture was significantly different in the South in the [pre-globalisation] era during which Standing argues the 'trend' for workers was 'away from money wages' and towards 'social income"' (165). But money wages are part of social income, not something different from it.

I started to develop the concept of social income when working in the Caribbean many years ago, and was puzzled by the fact that factories as well as plantations were combining low money wages with relatively high non-wage forms of remuneration. This was not forced on them. The intention was to stabilise labour supply and achieve proletarianisation. But they did so at the cost of persistently low productivity.

I later worked in sub-Saharan Africa, where another process was happening, where low money wages were combined with forced reliance on a relatively large component of social income, nonwage community benefits. This was brilliantly analysed by Giovanni Arrighi for what was then Rhodesia (Arrighi and Saul, 1973). It was deliberate non-proletarianisation.

In the 1980s, in the early globalisation era, I worked on labour markets in Malaysia, Thailand and the Philippines, and conducted surveys of workers in thousands of firms, many of which were multinationals. It was clear that managements were adopting a strategy of labour decommodification of core employees (the proletariat) and salariat, while indulging in extreme labour commodification for what was the emerging precariat, which consisted mainly of teenage women from kampungs (Malay villages).

Then in prolonged research in South Africa, I observed similar trends, as we did in surveys in Tanzania and Ethiopia. Given Scully's robust claims, it is perhaps ironic that the first empirical measure of the precariat was done for South Africa, which I did in 2007 using the official October Household Survey at the request of the Minister of Labour. ${ }^{15}$

Then in a global research programme in the ILO, we built data sets for over 150 countries, in which efforts were made to measure the structures of social income in different countries and the prevalence of precariat situations around the world. In the comprehensive report we measured labour securities in different countries and different types of firm, and also produced proxy

\footnotetext{
${ }^{14}$ As he also claims I have blinded myself (160), that seems quite a feat.

${ }^{15}$ Earlier, with others, I developed the framework in a book written as director of labour market research for President Mandela's Labour Market Commission. See Standing, Sender and Weeks (1996).
}

Global Labour Journal, 2016, 7(2), Page 198 
measures of degree of "informality" (ILO, 2005).

Finally, an opportunity arose to measure changes in the structure of social income in the industrialising Indian State of Gujarat. Through household-based surveys we found that while a salariat was emerging, with access to diverse non-wage benefits, the proletariat was small while many were entering precariat-type circumstances (Standing et al., 2010).

In short, there is no single "South" model, and the precariat perspective was not developed with "Northern lenses". For some time, the opposite might have been closer to the truth.

However, when working in Scandinavia in the 1980s, I concluded that the Swedish model - so revered by socialists and social democrats - was drably labourist. If somebody did not conform to the norms of labour, they were in trouble. Sweden decommodified labour by having a high ratio of non-wage payments to wages and was paternalistic, ultimately relying on workfare. I called this fictitious labour decommodification, because to obtain those non-wage benefits one had to be firmly linked to the labour market. ${ }^{16}$

Meanwhile, labour decommodification was reaching its endgame in the USSR and in China (Global South or North?). State socialism had remorselessly pursued policies that restructured social income in favour of non-wage forms of remuneration, while commodifying labour power, people, giving extreme "employment security". That accelerated the collapse of the Soviet system and the demise of China's dan wei system. In response, China raced to commodify labour, as has been the case in ex-Soviet Union countries. Those countries now have a huge precariat, as highlighted in the books, and as shown by ongoing research by scholars in those countries.

In sum, only a very unsympathetic reading could conclude that analysis of the precariat is based on ignorance or disregard of developments in whatever notion of "South" is used.

\section{Concluding Reflections}

Thousands of people have written to me about their feeling part of the precariat. Many are in developing countries. Of course, differences of emphasis come up. However, feelings are remarkably similar - feelings of facing a life of "no future", of relations of production of unstable labour and lack of occupational security, of having money wages that are volatile and unpredictable, and losing the five rights of citizens. These define their class status.

The terms "social exclusion" and "marginalisation" are unhelpful in understanding the precariat and the class dynamics of contemporary capitalism (tertiary, rentier, etc.). Exclusion implies expulsion and being jettisoned from the mainstream; marginalisation suggests the same plus being pushed into the social margins. The precariat is becoming the mainstream.

Language and vocabulary matter, and a plea to fellow travellers, even those opposed to my line of reasoning, is that we revise our vocabulary to meet twenty-first century realities, rather than rely on tired words and ways of expression derived from the nineteenth century, which may have been progressive and appealing for much of the twentieth century but which have lost their resonance now.

\footnotetext{
16 Recall that a commodity is a good that is subject to market forces. The labourist error was to decommodify labour, the activity. Marx defined labour as "the alienation of activity". In an understandably controversial section of the final chapter of The Precariat, I advocated the "full commodification of labour" and the decommodification of labour power, people.
} 
Finally, a word on the book's title. Erik Wright made one slip in his paper that gave the game away, and he did it twenty times. He gave the book the wrong title. If you are critiquing somebody's book, at least get the title right. But the slip is significant, since the book is an attempt to outline $\underline{A}$ Precariat Charter, which reflects ideas that crystallised while participating in hundreds of meetings in various countries.

The book was set to be published on the $800^{\text {th }}$ anniversary of what became the Magna Carta, the first class-based set of demands made against the state. I posed the double question, "What would a precariat charter look like in 2015 , and how would it differ from what a proletariat charter might have looked like in 1915?" Obviously, in any particular country at any point of development, the contents and priorities would differ. But the essence of any precariat charter should be about a progressive revival of the Great Trinity for the twenty-first century.

\section{REFERENCES}

Arrighi, G. and J. Saul (1973) Essays on the Political Economy of Africa. New York and London: Monthly Review Press.

International Labour Organisation (ILO) (2005) Economic Security for a Better World. Geneva: ILO.

Jankiewicz, S. (2012) A Dangerous Class: The Street Sellers of Nineteenth-century London. Journal of Social History, 46(2): 391-415.

Standing, G. (1999) Global Labour Flexibility: Seeking Distributive Justice. Harmondsworth: Macmillan.

Standing, G. (2009) Work after Globalisation: Building Occupational Citizenship. Cheltenham: Elgar.

Standing, G. (2011) The Precariat: The New Dangerous Class. London and New York: Bloomsbury.

Standing, G. (2014a) Why the Precariat is not a "Bogus Concept". Open Democracy, 4 March 2014. Available online at http://www.opendemocracy.net/print/79901.

Standing, G. (2014b) Understanding the Precariat through Labour and Work. Development and Change, 45(5): 963-980.

Standing, G. (2014c) A Precariat Charter: From Denizens to Citizens. London: Bloomsbury Academic.

Standing, G., J. Sender and J. Weeks (1996) The South African Challenge: Restructuring the Labour Market. Geneva: ILO.

Standing, G., J. Unni, R. Jhabvala and R. Uma (2010) Social Income and Insecurity: A Study in Gujarat. London and New Delhi: Routledge.

\section{BIOGRAPHICAL NOTE}

GUY STANDING is an economist and research professor at the School of Oriental and African Studies, University of London. He was previously Director of the Socio-Economic Security Programme of the International Labour Organisation. [Email: guystanding@standingnet.com] 